\title{
The Length - Weight Relationship and maximum length of Umbrina cirrosa (Linnaeus, 1758)
}

\author{
Mehmet Aydın ${ }^{1}$ (D) Adil Sözer² (D)
}

Cite this article as: Aydin, M. \& Sozer, A. (2020). The length - weight relationship and maximum length of Umbrina cirrosa (linnaeus, 1758). Aquatic Sciences and Engineering, 35(4), 100-4.

ORCID IDs of the author: M.A. 0000-0003-1163-6461; A.S. $0000-0002-8674-1461$

'Ordu University, Fatsa Faculty of Marine Science, Ordu, Turkey

\section{Submitted:}

05.03.2020

Revision Requested: 13.05.2020

Last Revision Received: 16.05.2020

\section{Accepted:}

18.05.2020

Online published:

08.06.2020

Correspondence:

Mehmet Aydın

E-mail:

maydin69@hotmail.com

(C) Copyright 2020 The Author(s)

Available online at

https://dergipark.org.tr/ase

\begin{abstract}
In this study, length-weight relationship of Umbrina cirrosa was determined in the Black Sea while giving a maximum length and weight record for this species. A total of $102 \mathrm{U}$. cirrosa were sampled by using trammel nets between 2018 and 2019 in the southern Black Sea. The mean length and the mean weight of the specimens were estimated as $32.4 \mathrm{~cm} \pm 15.02$ (4.8-94) and $613.1 \mathrm{~g} \pm 962.69$ (1.0-7051.1), respectively. One of the sampled species was measured as $94 \mathrm{~cm}$ in total length, weighed $7051.1 \mathrm{~g}$, and was found to be 5 years old. These measurements prove this specimen to be the largest individual for the Turkish coasts. The length-weight relationship was described as $W=0.009 L^{3.0541}\left(R^{2}=0.9962\right)$ with positive allometric growth for all individuals. This is the first study conducted for $U$. cirrosa in the Black Sea while the maximum size record is given for all Turkish coastal waters.
\end{abstract}

Keywords: Umbrina cirrosa, length-weight parameters, maximum weight, maximum total length, Black Sea, Turkey

\section{INTRODUCTION}

The Shi drum, Umbrina cirrosa (Linnaeus 1758), is a member of the Sciaenidae family (Fischer et al., 1987) and has a great economic value in commercial fishing (Fabi and Fiorentini, 1993; Mylonas et al., 2000). It is a demersal fish largely spread from the Eastern Atlantic to the Mediterranean and the Black Sea living within a depth range of 0 to $100 \mathrm{~m}$ (Fischer et al., 1987). The Shi drum is a bottom-dwelling species, mainly feeding on invertebrates and fish (Abellan and Basurco 1999; Lobry et al., 2003). Smaller individuals generally prefer muddy habitats of coastal zones and estuaries (Fischer et al., 1987). When the sea has a heavy condition, wave breaking action stirs up the benthic in coastal areas and reveals the creatures that the Shi drum feeds on. They generally approach the coastal area where the waves break for feeding purpose (personal observation).
Fischer et al., (1987) stated that they are usually between $30-80 \mathrm{~cm}$, but they can grow up to 100 $\mathrm{cm}$. Chao and Trewavas (1990) measured a 40 $\mathrm{cm}$ of common length with a maximum size of $73 \mathrm{~cm}$. According to FishBase (2020), this species can grow up to a maximum size of $73 \mathrm{~cm}$ and $3.1 \mathrm{~kg}$. In Turkish territorial waters, U. cirrosa are fished using trammel nets and trawls by fishermen in the Mediterranean Sea, Aegean Sea, Sea of Marmara, and Black Sea.

The total average production of $U$. cirrosa was 32.1 tons in Turkey between the years 20082018 (TUIK, 2019). It has an average price of $\$$ 10 per $\mathrm{kg}$. Due to its rapid growth, it has been used as a new species in aquaculture in the Mediterranean since the 2000s (Melotti et al., 1995; Mylonas et al., 2000; Barbaro et al., 2002; Mylonas et al., 2004; Koumoundouros et al., 2005).

There are no studies in the literature focusing 
on the population structure of the natural stocks of this species in Turkish territorial waters. In this study, the length-weight relationship together with the maximum total length, total weight and age determination are given for this species.

\section{MATERIALS AND METHODS}

A total of 102 specimens of $U$. cirrosa were caught by using trammel nets (40-60-80 mm mesh size) between 2018 and 2019 in the Southern Black Sea region (between 41012'20.94"N $37^{\circ} .18^{\prime} .43 .57^{\prime \prime} \mathrm{E}$ and $\left.41^{\circ} .28^{\prime} .02 .52^{\prime \prime} \mathrm{N}-41^{\circ} 27^{\prime} 53.86^{\prime \prime} \mathrm{E}\right)$ (Figure 1). It can only be sampled efficiently when the tide is high because the catching success is very low when the sea is calm.

Caught fish samples were transported in iceboxes to the Laboratory of Fatsa Faculty of Marine Sciences, Ordu University. The length and weight of the samples were measured with the accuracy of $1 \mathrm{~cm}$ and $0.1 \mathrm{~g}$ respectively for all specimens (Table 1). Sex determinations were made through macroscopic observation of the gonad. Chi-square $\left(\chi^{2}\right)$ analysis was used to test for significant differences between the sex ratio.

The total length-weight relationship (LWR) of the species was estimated by applying the exponential regression model, $\mathrm{W}=$ $a T L{ }^{b}$, where $a$ and $b$ are constants (Ricker, 1975). LWR relationship was performed for three groups; by using only males, only females, and all samples. The Pauly's t-test was used to compare the "b" values (Pauly, 1984) to determine whether there is any significant difference or not. Sagitta otolith was used for the age determination of the maximum sized fish.

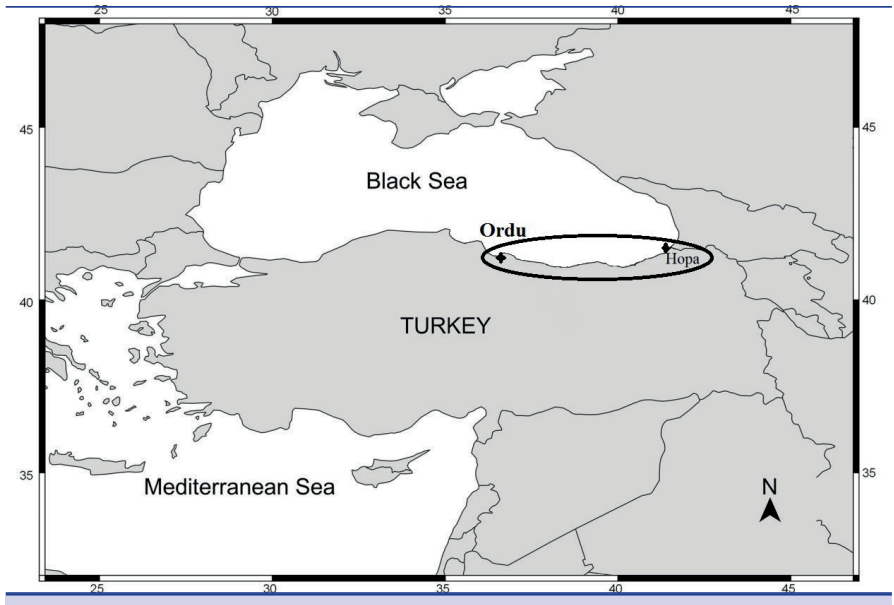

Figure 1. The map showing the sampling area.

\section{RESULTS AND DISCUSSION}

A total of 102 (52 female, 46 male and 4 immature) specimens were examined. The ratio of female to male specimens was found as 1:1.13. The difference between the sex ratios was not found to be statistically significant $\left(\chi^{2}=0.51, d f=1, p>0.05\right)$.

The mean total length and the mean weight of the specimens were estimated as $32.4 \mathrm{~cm} \pm 15.02(4.8-94)$ and $613.1 \mathrm{~g} \pm 962.69$ (1.0-7051.1) respectively (Table 1$)$.

One of the female individuals sampled from Hopa was measured as $94 \mathrm{~cm}$ in total length (Figure 2), weighed $7051.1 \mathrm{~g}$ (gonad weight: $190 \mathrm{~g}$ ) and found to be 5 years old (Figure 3). These numbers make it the largest individual for Turkish waters.

When the $U$. cirrosa population in the Black Sea examined, the highest percentage was observed for 35-40 cm TL (21\%) length group (Figure 4).

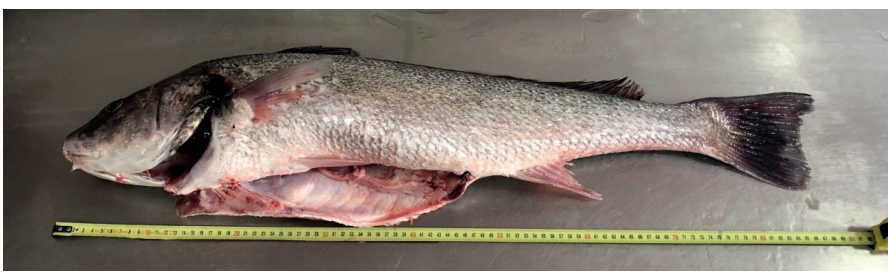

Figure 2. The largest individual from the Black Sea.

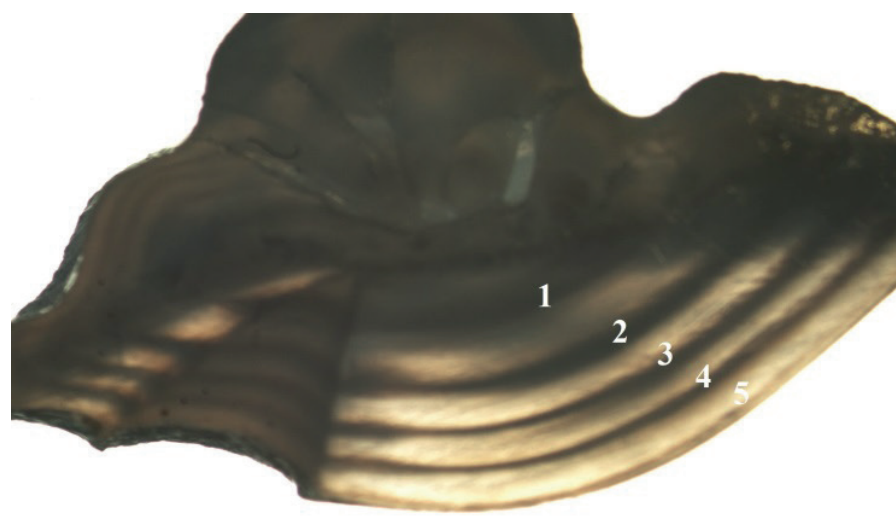

Figure 3. A thin stained otolith section of Umbrina cirrosa (total length $94 \mathrm{~cm}$, weight $7051.1 \mathrm{~g}$ ) aged 5 years old.

Table 1. Mean and standard deviation, maximum, minimum values for length $(L)$ and weight $(W)$ parameters of each sex of Umbrina cirrosa.

\begin{tabular}{|c|c|c|c|c|c|c|c|c|c|c|}
\hline$S$ & \multicolumn{5}{|c|}{$L(\mathrm{~cm})$} & \multicolumn{5}{|c|}{$W(g)$} \\
\hline$\Sigma$ & 32.4 & \pm & 15.02 & 4.80 & 94.00 & 613.10 & \pm & 962.69 & 1.00 & 7051.10 \\
\hline$\hat{0}$ & 32.00 & \pm & 10.29 & 14.60 & 50.30 & 463.80 & \pm & 356.72 & 28.96 & 1330.00 \\
\hline
\end{tabular}

$\Sigma:$ All, ô: Male, $q$ : Female, S: Sex, N: Number of individuals, Min: Minimum, Max: Maximum, SD: Standard Deviation 
The length-weight relationship for all samples (males and females) was estimated as $W=0.009 L^{3.0541}\left(R^{2}=0.996\right)$ with a positive allometric growth. The length-weight relationship for the female, male groups, and all individuals are given in Figure 5.

The " $b$ " value estimations from the length-weight relationship of $U$. cirrosa are 3.054 for all individuals, 2.995 for females and 3.029 for males. The value of " $b$ " is only slightly different than 3 for all individuals and is not significantly different than 3 for the female and male groups with $\mathrm{p}>0.05$ (Table 2). Positive al-

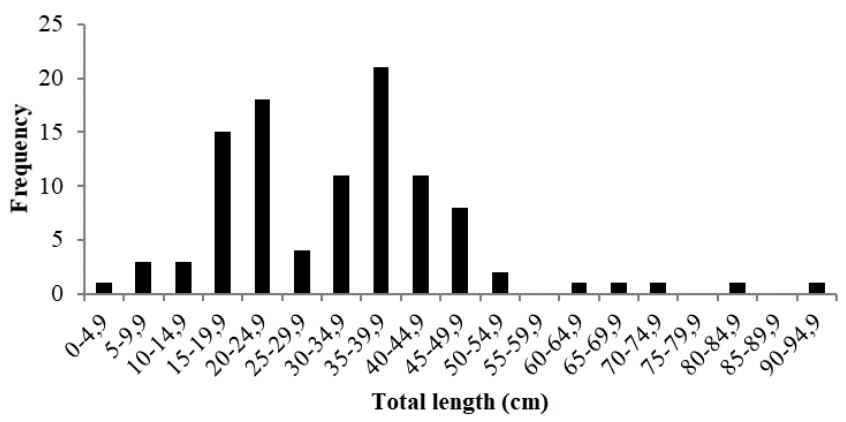

Figure 4. Length frequency distributions of Umbrina cirrosa collected from the southern Black Sea region.
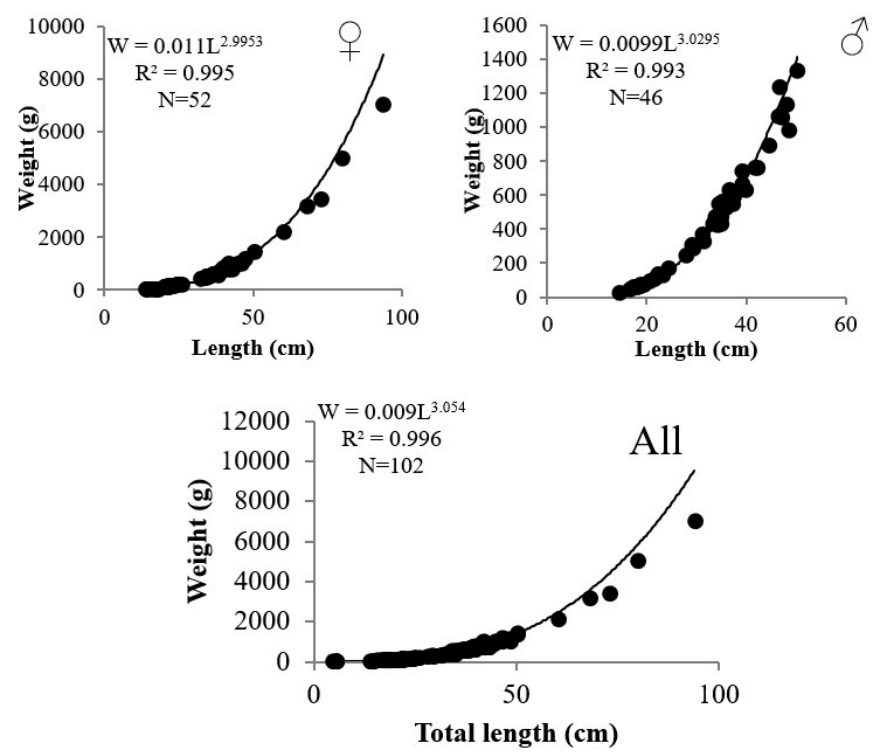

Figure 5. The Length-weight relationship for Umbrina cirrosa collected from the Southern Black Sea region. lometric growth values were observed for U. cirrosa for males and all individuals, while the females showed an isometric growth (Figure 5).

$U$. cirrosa is a species with a high rate of catching when it approaches the coastal areas for feeding purpose, especially when the sea is heavy with big waves stirring up the bottom (Dr. Mehmet AYDIN observations). To sample the species, sampling should be done under this type of weather conditions, when fishing is quite difficult as expected.

In addition to this, due to the high preference of this fish in restaurants, this species is sold directly to the restaurants by commercial fishers, and only a very small portion of the samples can be obtained from commercial fishers. Therefore, the number of samples in this study is lower than the number of samples for the researches focusing on other similar species. If we look at the previous studies about this species, we see that the sample numbers are either very low or the size of the samples has a narrow range including mostly juvenile individuals (Table 3 ). Considering the size distribution of the samples for this study together with the smallest and the largest individuals of the samples, it can be said that the size structure of the natural population is more realistically represented in this study compared with the previous researches of the literature.

In the catalogue book of Fischer et al. (1987), it is stated that this species theoretically has the potential of growing up to 100 $\mathrm{cm}$ length. Additionally, based on the study Chao and Trewavas (1990) carried out, it grows to $73 \mathrm{~cm}$ in length, and a record was given in FishBase (2020) with the size of $73 \mathrm{~cm}$ length and $3.1 \mathrm{~kg}$ weight. The maximum length $(94 \mathrm{~cm})$ and weight $(7051.1 \mathrm{~g})$ values given in this study is the largest length and weight record for this species in the Black Sea region. The length-weight relationship was described as $W=0.009 L^{3.0541}$ for all samples. In previous studies, the smallest and the largest " $b$ " values were found to be 2.917 (Bolognini et al., 2013) and 3.419 (Başusta et al., 2019, see Table 3) respectively for this species. In this study, the $b$ value was estimated as 3.054 , which is within the limits of the smallest and largest " $b$ " range given by the previous studies. Additionally, a relatively high "b" value by Başusta et al., (2019) conflicting with our results can be due to the juvenile profile of the sampled individuals or due to the fishing gear used in the sampling of that research. The age of the maximum-sized individual sampled in the study was determined to be 5 years old $(94 \mathrm{~cm}, 7051.1 \mathrm{~g})$, which is comparable with the values given by Arneri et al. (1998) for the individuals aged 3 years old (length $67 \mathrm{~cm}$ and weight $3200 \mathrm{~g}$ ).

Table 2. The Length-weight relationship parameters for male, female groups and all individuals for Umbrina cirrosa sampled from the Southern Black Sea region.

\begin{tabular}{cccccccc}
\hline $\mathbf{S}$ & $\mathbf{N}$ & $\mathbf{a}$ & $\mathbf{b}$ & 95\% Confidence Interval (+SD) & $\mathbf{R}^{2}$ & Pauly t-test & $\mathbf{P}$ \\
\hline $\boldsymbol{\Sigma}$ & $98+4$ & 0.009 & 3.054 & $3.016-3.091(+0.018)$ & 0.996 & 2.870 & $>0.05$ \\
+ & 52 & 0.011 & 2.995 & $2.993-3.057(+0.030)$ & 0.995 & 0.152 & $<0.05$ \\
$\hat{\gamma}$ & 46 & 0.009 & 3.029 & $2.952-3.106(+0.038)$ & 0.993 & 0.769 & $<0.05$ \\
\hline
\end{tabular}

$\Sigma:$ All, o : Male, + : Female, S: Sex, N: Number of individuals, SD: Standard deviation, a: Intercept, b:Slope, R2: Determination coefficient, P: Probability of the t-test ( $H_{0}$ : $b=3$ ) (4 immature). 
Table 3. The length- weight relationships of Umbrina cirrosa from different areas.

\begin{tabular}{|c|c|c|c|c|c|c|c|c|c|}
\hline $\mathbf{N}$ & $\begin{array}{l}\mathrm{L}_{\min }-\mathrm{L}_{\max } \\
(\mathrm{cm})\end{array}$ & $\begin{array}{l}\text { Mean } \\
(\mathrm{cm})\end{array}$ & $\begin{array}{c}W_{\min }-W_{\max } \\
\text { (g) }\end{array}$ & Mean (g) & a & b & $\mathbf{R}^{2}$ & Region & References \\
\hline \multirow[t]{2}{*}{41} & $36.2-66.5$ & $42.20 \pm 0.918$ & $508-2915$ & $794.8 \pm 68.3$ & - & - & - & Eastern Adriatic Sea & (Dulčić and Kraljević, 1996) \\
\hline & $11-16$ & 13.5 & - & 24.1 & - & - & - & Abu-Qir Bay (Egypt) & (Faltas et al., 1998) \\
\hline 9 & $6.5-24.7$ & - & - & - & 0.0119 & 2.985 & 0.997 & $\begin{array}{l}\text { Porto-Lagos } \\
\text { (NE Aegean) }\end{array}$ & (Koutrakis and Tsikliras, 2003) \\
\hline 10 & $11-54$ & - & - & - & - & - & - & - & (Cruz and Lombarte, 2004) \\
\hline 44 & $33.1-47$ & - & - & - & 0.0115 & 3.060 & 0.977 & $\begin{array}{c}\text { River Mirna, northern } \\
\text { Adriatic }\end{array}$ & (Dulčić and Glamuzina, 2006) \\
\hline 537 & $18.5-49.5$ & $27.1 \pm 4.0$ & $93-1281$ & $240.9 \pm 133.6$ & 0.015 & 2.917 & 0.963 & Adriatic Sea & (Bolognini et al., 2013) \\
\hline 2 & $2-42$ & $31 \pm 2.89$ & $200-817$ & $508.5 \pm 81.02$ & - & - & - & Sinop (Black Sea) & (Bat et al., 2018) \\
\hline 218 & $13.5-26.8$ & - & $19.12-214.04$ & - & 0.0028 & 3.419 & 0.989 & $\begin{array}{c}\text { Mersin Bay } \\
\text { (Mediterranean) }\end{array}$ & (Başusta et al., 2019) \\
\hline 102 & $4.8-94$ & $32.4 \pm 15.02$ & $1.0-7051.1$ & $613.1 \mathrm{~g} \pm 962.6$ & 0.009 & 3.054 & 0.996 & Southern Black Sea & Present study \\
\hline
\end{tabular}

\section{CONCLUSION}

In conclusion, this study is very important in terms of being the first study with a sample group covering all length groups of this species while giving a weight-height relationship similar to the natural population. Nevertheless, age determination of an individual of this size both in weight and length had never been done before. The population of this species is spread over a wide area covering the Black Sea, the Mediterranean Sea and the Atlantic Ocean and has a high commercial value, therefore demans further studies in detail.

Conflict of interests: The author declares that they have no conflict of interest.

Ethics committee approval: All applicable international, national and/or institutional guidelines for the care and use of animals were followed by the author.

\section{Funding: -}

\section{Acknowledgments: -}

\section{Disclosure: -}

\section{REFERENCES}

Abellan, E. \& Basurco, B. (1999). Marine finfish species diversification: current situation and prospects in Mediterranean aquaculture. Cah Options Méditer Serie B Etudes et Recherches, 24, 1-139.

Arneri, E., Colella S. \& Giannetti, G. (1998). A method for the age determination of two Mediterranean sciaenids, Sciaena umbra (Linnaeus, 1758) and Umbrina cirrosa (Linnaeus, 1758). Rapp. Comm. Int. Mer Médit., 35, 366-367.

Barbaro, A., Francescon, A., Bertotto, D., Bozzato, G., Di Maria, I., Patarnello, P., Furlan, F. \& Colombo, L. (2002) More effective induction of spawning with long-acting $\mathrm{GnRH}$ agonist in the shi drum, Umbrina cirrosa L (Sciaenidae, Teleostei), a valuable candidate for Mediterranean mariculture. Journal of Applied Ichthyology, 18, 192-199. [CrossRef]

Başusta, N., Başusta, A., \& Demiroğlu, E. (2019) Length-Weight Relationships and Condition Factor of Umbrina cirrosa Inhabiting North-Eastern Mediterranean Sea. Ecological Life Sciences, 14, 125128. [CrossRef]
Bat, L., Şahin, F., Sezgin, M., Gönener, S., Erdem, E. \& Ozsandikci, U. (2018). Fishery of Sinop coasts in the Black Sea surveys. European Journal of Biology, 77(1), 18-25. [CrossRef]

Bolognini, L., Domenichetti, F., Grati, F., Polidori, P., Scarcella, G. \& Fabi, G. (2013). Weight-length relationships for 20 fish species in the Adriatic Sea. Turkish Journal of Fisheries and Aquatic Sciences, 13(3), 555-560. [CrossRef]

Chao, L. N. \& Trewavas, E. (1990). Sciaenidae. p. 813-826. In J.C. Quero, J. C. Hureau, C. Karrer, A. Post and L. Saldanha (eds.) Check-list of the fishes the eastern tropical Atlantic (CLOFETA). JNICT, Lisbon; SEI, Paris; and UNESCO, Paris. Vol. 2.

Cruz, A., Lombarte, A. (2004). Otolith size and its relationship with colour patterns and sound production. Journal of Fish Biology, 65, 15121525. [CrossRef]

Dulčić, J. \& Glamuzina, B. (2006). Length-weight relationships for selected fish species from three eastern Adriatic estuarine systems (Croatia). Journal of Applied Ichthyology, 22, 254-256. [CrossRef]

Dulčić, J. \& Kraljević, M. (1996). Weight-length relationships for 40 fish species in the eastern Adriatic (Croatian waters). Fishery Research, 28, 243-251. [CrossRef]

Fabi, G. \& Fiorentini, L. (1993). Catch and growth of Umbrina cirrosa (L.) around artificial reefs in the Adriatic Sea. Bollettino di Oceanologia Teorica ed Applicata, 11, 235-242.

Faltas, S. N, Akel, E. H. K. \& Abdala, A. (1998). A study on trash catch of the bottom trawl along Port-Said Coast, Egypt. BulL Nat Inst o/ Oceanogr Fish, 24, 349-363

Fischer, W., Bauchot, M. L. \& Schneider, M. (1987). Fiches FAO identification des espèces pour les besoins de la pêche. (Rèvision 1). Mediterranèe et Mer Noir. Zone de Pêche 37. Vol. II Vertèbres. FAO, Rome, $600 \mathrm{pp}$.

FishBase, (2020). https://www.fishbase.se/summary/1306

Koumoundouros, G., Kouttouki, S., Georgakopoulou, E., Papadakis, I., Maingot, E., Kaspiris, P., Kiriakou, Y., Georgiou, G., Divanach, P., Kentouri, M. \& Mylonas, C. C. (2005). Ontogeny of the shi drum Umbrina cirrosa (Linnaeus 1758), a candidate new species for aquaculture. Aquaculture Research, 36, 1265-1272. [CrossRef]

Koutrakis, E. T. \& Tsikliras, A. C. (2003). Length-weight relationships of fishes from three northern Aegean estuarine systems (Greece). Journal of Applied Ichthyology, 19, 258-260. [CrossRef]

Lobry, J., Mourand, L., Rochard, E. \& Elie, P. (2003). Structure of the Gironde estuarine fish assemblages: a comparison of European estuaries perspective. Aquat Living Resour, 16, 47-58. [CrossRef]

Melotti, P., Roncarati, A., Gennari, L. \& Mordenti, O. (1995). Trials of induced reproduction and larval rearing of curb (Umbrina cirrosa L). Oebalia, 21, 37-42. 
Aquat Sci Eng 2020; 35(4): 100-4

Aydın and Sözer. The Length - Weight Relationship and maximum length of Umbrina cirrosa (Linnaeus, 1758)

Mylonas, C. C., Kyriakou, Y., Sigelaki, I., Georgiou, G., Stephanou, D. \& Divanach, P. (2004). Reproductive biology of the Shi Drum (Umbrina cirrosa) in captivity and induction of spawning using GNRHA. The Israeli journal of aquaculture=Bamidgeh 56, 75-92.

Mylonas, C. C., Georgiou, G., Stephanou, D., Atack, T., Afonso, A. \& Zohar, Y. (2000). Preliminary data on the reproductive biology and hatchery production of the shi drum (Umbrina cirrosa) in Cyprus. In: B. Basurco (eds.). Chaiers Options Méditerranéennes, Mediterranean
Marine Aquaculture Finfish Species Diversification. CIHEAM, Zaragoza Spain. 312 pp.

Pauly, D. (1984). Fish population dynamics in tropical water: a manual for use with programmable calculators. ICLARM Studies and Reviews 8. $325 \mathrm{pp}$

Ricker, W. E. (1975). Computations and Interpretation of Biological Statistics of Fish Populations. 